\title{
e Complex Regional Pain Syndrome Type I, a Debilitating and Poorly Understood Syndrome. Possible Role for Pulsed Electromagnetic Fields: A Narrative Review
}

\author{
Stefania Pagani BSc, Francesca Veronesi PhD, Nicolò Nicoli Aldini MD, and Milena Fini MD
}

From: Laboratory of Preclinical and Surgical Studies, Rizzoli Orthopedic Institute, Bologna,

Italy

Address Correspondence: Francesca Veronesi, PhD Laboratory of Preclinical and Surgical Studies Rizzoli Orthopedic Institute via Di Barbiano $1 / 10$ 40136 Bologna, Italy E-mail:

francesca.veronesi@ior.it

Disclaimer: see pg.E 820. Conflict of interest: Each author certifies that he or she, or a member of his or her immediate family, has no commercial association (i.e., consultancies, stock ownership, equity interest, patent/licensing arrangements, etc.) that might

pose a conflict of interest in connection with the submitted manuscript.

Manuscript received: 09-05-2016

Revised manuscript received: 12-14-2016

Accepted for publication: 02-06-2017

Free full manuscript: www.painphysicianjournal.com
Background: Complex regional pain syndrome type I (CRPS-I), also called algodystrophy, is a complex syndrome characterized by limb pain, edema, allodynia, hyperalgesia and functional impairment of bone with a similar clinical picture of osteoporosis, including an increased release of various pro-inflammatory neuropeptides and cytokines.

Several treatments have been proposed for CRPS-I, but due to the poor outcome of conventional drugs and the invasiveness of some techniques, expectations are now directed towards new resources that could be more effective and less invasive.

Objective: In the light of preclinical evidence, which underlined pulsed electromagnetic fields' (PEMFs) properties on osteoblasts (OBs), osteoclasts (OCs), and pathologies with an inflammatory profile, the present review aims to investigate whether there is a rationale for the use of PEMFs, as a combined approach, in CRPS-I.

Study Design: This review analyzed the 44 in vitro and in vivo studies published in the last decade that focused on 2 main aspects of CRPS-I: local osteoporosis (OP) and inflammation.

Setting: Not applicable.

Methods: This review includes in vitro and in vivo studies found with a PubMed and Web of Knowledge database search by 2 independent authors. The limits of the search were the publication date between January 1, 2006, and January 1, 2016, and English language. In detail, the search strategy was based on: 1) CRPS-I or algodystrophy; 2) OP, OCs, and OBs; and 3) inflammatory aspects.

Results: The included studies looked at the relationship between PEMFs and OCs (2 in vitro studies), osteoporotic animal models (8 in vivo studies), OBs (20 in vitro studies), inflammatory cytokines, and reactive oxygen species. They also tried to define the molecular cell pathways involved (5 in vivo and 9 in vitro studies on inflammatory models). It was observed that PEMFs increased OC apoptosis, OB viability, bone protein and matrix calcification, antioxidant protein, and the levels of adenosine receptors, while it decreased the levels of pro-inflammatory cytokines.

Limitations: Data from clinical trials are scarce; moreover, experimental conditions and PEMF parameters are not standardized.

Conclusions: The present review underlined the rationale for the use of PEMFs in the complex contest of CRPS-I syndrome, in combination with conventional drugs.

Key words: Complex regional pain syndrome type I, algodystrophy, pulsed electromagnetic field stimulation, osteoporosis, inflammation, osteoclasts, osteoblasts, pain

Pain Physician 2017; 20:E807-E822 
omplex regional pain syndrome type I (CRPS-I), also called algodystrophy, or reflex sympathetic dystrophy (RSD), is a painful syndrome affecting limbs. It is characterized by sensory and vasomotor disorders, edema, and functional impairment of bone. It was also known as Sudeck's disease, due to its first clinical description in 1900 by the German surgeon Paul Sudeck (1866 - 1945) (1).

According to the modern classification, CRPS Type $I$ is characterized by the absence of an obvious nerve damage, whereas CRPS type II shows the presence of a peripheral nervous lesion $(2,3)$.

Treatment of CRPS-I is complex, and so is the clinical presentation of this syndrome.

Another obstacle in the study of this morbid condition is the difficulty to obtain a satisfactory reliable preclinical model. Indeed, animal models, with features similar to those observed in patients suffering from CRPS-I, can be found in the literature, but they are obviously not effective for a correct comparison of suffering pattern and pain severity in animals and humans (4).

The main features of CRPS-I are pain, allodynia, and hyperalgesia, which represent a severe burden for patients, heavily interfering with their quality of life.

The local release of pro-inflammatory neuropeptides and cytokines seems to be the pathway that triggers and maintains the disease.

Omoigui (5) observed that the origin of every kind of pain is an inflammatory process and its local manifestations. Each painful syndrome has a specific inflammatory profile related to the pattern of in situ inflammatory mediators. This inflammatory profile changes among different people and in the same patient at different times. According to Varenna and Zucchi (4), a local process of neuro-inflammation is involved in the first stage of the disease (edema, eritrosis, increased local temperature, and sweating); while in the more advanced phases, impairment of microcirculation takes over (the so called "dystrophic" or "cold" phase).

Multiple mediators are involved in the inflammatory profile of CRPS-I and its complications, in particular, pro-inflammatory cytokines, such as interleukins 1 , 6, 8, 2, 17 (IL-1, IL-6, IL-8, IL-2, IL-17), leukemia inhibitory factor (LIF), tumor necrosis factor- $\alpha$ (TNF- $\alpha$ ), and free radicals (such as nitric oxide) $(6,7)$.

In addition, the skeletal tissue is also involved in the clinical picture of CRPS-I. The inflammatory mediators, present in the lesion, increase bone resorption, further enhanced by disuse due to pain, resulting in the appearance of localized osteoporosis (OP).
Several drugs were proposed for effective treatment, such as analgesics (non-steroidal anti-inflammatory drugs and opioids), anesthetics, anticonvulsants, antidepressants, muscle relaxants, corticosteroids, calcitonin, bisphosphonates, and free radical scavengers (8). The control of pain is therefore paramount in CRPS-I treatment, because of the highly debilitating consequences of its symptoms; however, several patients seem to be refractory to the treatments listed above. Due to the poor outcome of conventional drugs and the invasiveness of some techniques, expectations are now directed towards further resources that could be effective and less invasive.

In this scenario, pulsed electromagnetic fields (PEMFs), whose effectiveness in the control of various painful and inflammatory disorders is well assessed, show interesting and promising properties.

PEMFs gained popularity in medicine starting from the 1970s, although the first interest in the effects of magnetic forces on the human body can be traced back several centuries ago. In 1979 the FDA approved the use of PEMFs for bone growth stimulation, i.e., in nonunions (9). Afterwards, the range of possible applications has been widened, including multiple sclerosis, osteoarthritis (OA) of the knee, fibromyalgia, loosened hip prostheses, cervical OA, congenital pseudoarthrosis, delayed union of fractures, chronic rotator cuff tendinitis, osteonecrosis of the hip, and chronic venous ulcers (10). In 1989 Rubin et al (11) proposed the use of PEMF in preventing OP. Electromagnetic stimulation of tissues can be obtained by means of electrodes directly in contact with the skin or by generators placed near the body.

Overall, the ultimate mechanism of action of PEMFs can be identified by their influence on the ion balance and membrane exchanges at the cellular level. The anti-flogistic activity of PEMFs can be ascribed to their action on adenosine receptors, whose activation produces several anti-inflammatory responses.

PEMF stimulation has been studied and proposed for the regeneration of musculoskeletal tissues such as cartilage, bone, tendon, and ligament. Several preclinical studies have shown PEMF anabolic and anti-inflammatory activity in musculoskeletal tissues. They also improve mesenchymal stem cells (MSC) osteoblastic differentiation, at the expense of adipogenic differentiation and, at the same time, they stimulate the production of extracellular matrix (ECM) components (12-38). There are no specific studies about PEMF effectiveness in CRPS-I therapy, as single or combined treatment, ex- 
cept the study of Durmus et al (39) reported in a recent Cochrane systemic review. In this clinical trial PEMFs were used in association with calcitonin and stretching exercises, but their effects were similar to those of placebo for the treatment of pain or range motion. The evidence derived from this study was however defined of "low quality," and there are no other studies on a possible role or mechanism of PEMFs (39).

In the light of preclinical evidence, which underlined the above mentioned properties of PEMFs on bone tissues and in pathologies with an inflammatory profile, the present review aims to investigate whether there is a rationale for the use of PEMFs in a combined approach for CRPS-I treatment.

This paper reviews the in vitro and in vivo literature of the last decade that investigated 2 main aspects of CRPS-I: local OP and inflammation. The included studies deal with the relationship between PEMFs and osteoclasts (OCs), osteoporotic animal models, osteoblasts (OBs), inflammatory cytokines, and reactive oxygen species (ROS). also trying to define the molecular cell pathways involved.

\section{Methods}

As shown in Fig. 1, the review includes in vitro and in vivo studies found with a PubMed and Web of Knowledge database search by 2 independent authors. The limits of the search were the publication date between January 1, 2006, and January 1, 2016, and English language. In detail, the search strategy was based on: 1) CRPS-I or algodystrophy; 2) OP, OCs, and OBs; and 3) inflammatory aspects.

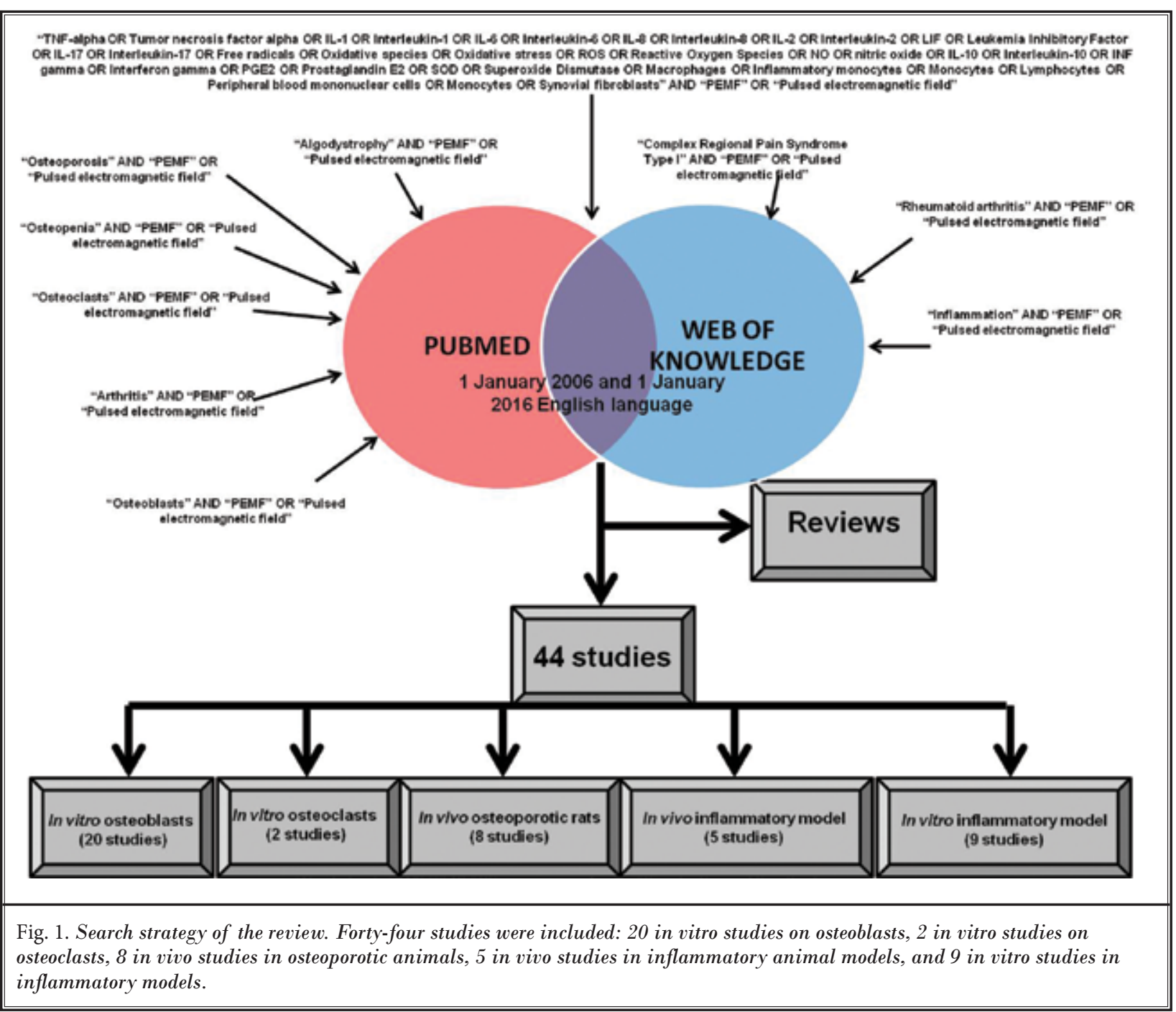


The employed key words were the following:

- for point 1) "Algodystrophy AND PEMF"; "Algodystrophy AND Pulsed electromagnetic field"; "Complex Regional Pain Syndrome Type I AND PEMF"; "Complex Regional Pain Syndrome Type I AND Pulsed electromagnetic field";

- for point 2) "Osteoporosis AND PEMF"; "Osteoporosis AND Pulsed electromagnetic field"; "Osteopenia AND PEMF"; "Osteopenia AND Pulsed electromagnetic field" "Osteoclasts AND PEMF"; "Osteoclasts AND Pulsed electromagnetic field"; "Osteoblasts AND PEMF"; "Osteoblasts AND Pulsed electromagnetic field";

- for point 3) "Inflammation AND PEMF"; "Inflammation AND Pulsed electromagnetic field"; "Rheumatoid arthritis AND PEMF"; "Rheumatoid arthritis AND Pulsed electromagnetic field"; "Arthritis AND PEMF"; "Arthritis AND Pulsed electromagnetic field"; "Pain AND PEMF"; "Pain AND Pulsed electromagnetic field." In addition, pro-inflammatory cytokines and cells, usually involved in an inflammatory pathology and in CRPS-I, were individually searched as "TNF-alpha OR Tumor necrosis factor alpha OR IL-1 OR Interleukin-1 OR IL-6 OR Interleukin-6 OR IL-8 OR Interleukin-8 OR IL-2 OR Interleukin-2 OR LIF OR Leukemia Inhibitory Factor OR IL-17 OR Interleukin-17 OR Free radicals OR Oxidative species OR Oxidative stress OR ROS OR Reactive Oxygen Species OR NO OR Nitric Oxide OR IL10 OR Interleukin-10 OR INF gamma OR Interferon gamma OR PGE2 OR Prostaglandin E2 OR SOD OR Superoxide Dismutase OR Macrophages OR Inflammatory monocytes OR Monocytes OR Lymphocytes OR Peripheral blood mononuclear cells OR Monocytes OR Synovial fibroblasts" AND "PEMF" OR "Pulsed electromagnetic field."

All the reviews, found with the point 1 search, were excluded.

\section{Results}

As also shown in Fig. 1, the search regarding point 1 did not give any results.

Points 2 and 3 search strategies gave a total of 44 in vitro and in vivo studies that were included in this review. Twenty of them regarded in vitro PEMF stimulation on OBs, 2 regarded in vitro studies on OCs, and 8 in vivo studies on osteoporotic animal models. Finally, 14/44 studies focused on inflammatory pathologies: 5 were in vivo models using mice and rats, while 9 were in vitro studies on pro-inflammatory cytokines and oxi- dative damage, 4 of which also investigated adenosine receptors in several cell types.

Figure 2 schematically represents the results of the studies found with the previously mentioned search strategies.

\section{Osteoblasts}

As it can be observed in Table 1, 8 in vitro studies evaluated primary OBs, harvested from human femoral heads of healthy participants (40) or from neonatal rat calvariae (34,41-46) and 10 in vitro studies evaluated the behavior of $O B$ cell lines of human and murine origin (SaOS2, UMR106-01, MC3T3-E1, and MG-63) after PEMF stimulation (47-56). Two studies evaluated both primary and $O B$ cell lines in the same study $(57,58)$. Among the above-mentioned studies, 7 studies observed OBs seeded onto different types of scaffolds, such as poly(lactide-co-glycolide) (PLGA) (34), polyurethane $(\mathrm{PU})(54,55)$, titanium $(\mathrm{Ti})(41,42,56)$, and calcium phosphate (CaP) discs (58).

Most of these studies employed PEMFs at 7.5, 15, and $75 \mathrm{~Hz}$ of frequency at different intensities and stimulation times.

In primary $\mathrm{OBs}$ an increase in cell proliferation, alkaline phosphatase (ALP) activity, and transforming growth factor- $\beta 1$ (TGF- $\beta 1$ ) was observed $(40,45,46)$. There was also a decrease in prostaglandin E2 (PGE-2) after PEMF stimulation, which seemed to have a synergic effect with bone morphogenetic protein 2 (BMP2) with regard to gene expression of ALP, osteocalcin (OCN), and collagen I (COLL I) (44). The mechanisms activated in OBs by PEMFs involved calcium ( $\mathrm{Ca++}$ ) movement and storage: intracellular and extracellular $\mathrm{Ca}++$ release, calmodulin, $\mathrm{P} 2$ receptor on the membrane and phospholipase C (PLC) pathways $(45,46)$, with particular regard to the wavelength features.

Only one study compared cell lines (MC3T3-E1) and primary cells from rat calvaria: the results showed no influence of PEMFs on MC3T3-E1 cells, but evidenced the ability of this stimulation to affect proliferation and differentiation, in a coordinated manner, on primary osteoblastic cells (57).

Cell line cultures showed an increase in gene expression and protein production of markers typically related to cell proliferation, differentiation, and bone synthesis. This was similar to primary cultures, but also included BMP2, frizzled class receptor 9 (FZD9), parathyroid hormone-related protein (PTHRP), insulin like growth factor (IGF-I), tissue inhibitor of metalloproteinases (TIMP1), and secreted protein acidic rich in cys- 


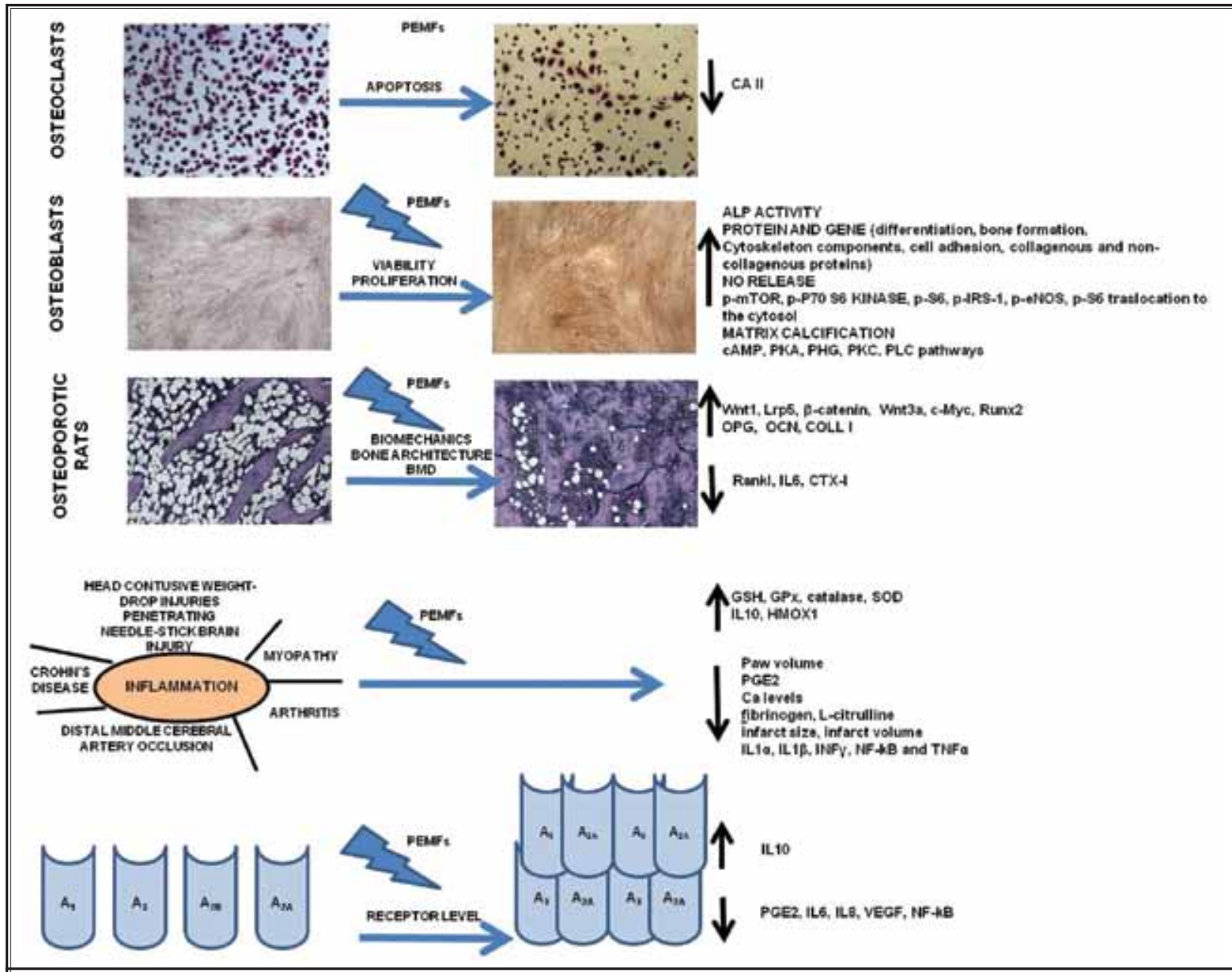

Fig. 2. A schematic representation of the 44 studies' results. The effects of PEMFs on osteoclasts, osteoblasts, osteoporotic animals, inflammatory pathologies, and adenosine receptor levels.

teine (SPARC), after the use of PEMFs. In addition, ALP activity and mineralization were increased. Conversely, there was a reduction in ECM degrading enzymes, such as metalloproteinases 11 (MMP11) and sclerostin (SOST) $(47-51,53)$. More in details, concerning the intracellular pathways, it was observed that PEMFs improved the phosphorilation and then the activation of mammalian target of rapamycin complex 1 (mTOR) (a regulator of cell growth and proliferation), P70 S6 kinase (regulator of protein synthesis and cell proliferation), S6 (regulator of cell proliferation), insulin receptor substrate 1 (IRS-1) (activator of MAP kinase signaling pathway), endothelial nitic oxide synthase (eNOS) (enzymes that produce NO) and pS6 traslocation to the cytosol (46-49). Studies looking at the mechanism of action of PEMFs revealed the involvement of several intracellular pathways, resulting in the improvement of cell growth and proliferation, as well as regulation of protein synthesis (4851). Special attention should be paid to the trend and ratio of osteoprotegerin (OPG) and receptor activator of NF-kappaB ligand (RANKL), key factors for osteoclastogenesis, since their expression showed fluctuations after different PEMF stimulations $(41,42,47-53,55,56)$.

Despite the different origin and types of the OBs employed, the studies on OBs, seeded onto a scaffold, showed that PEMFs significantly improved cell proliferation and viability, matrix calcification, and nitric oxide (NO) release. Again, the authors evaluated gene expression and protein production of the main actors of bone differentiation and activity, including transcrip- 


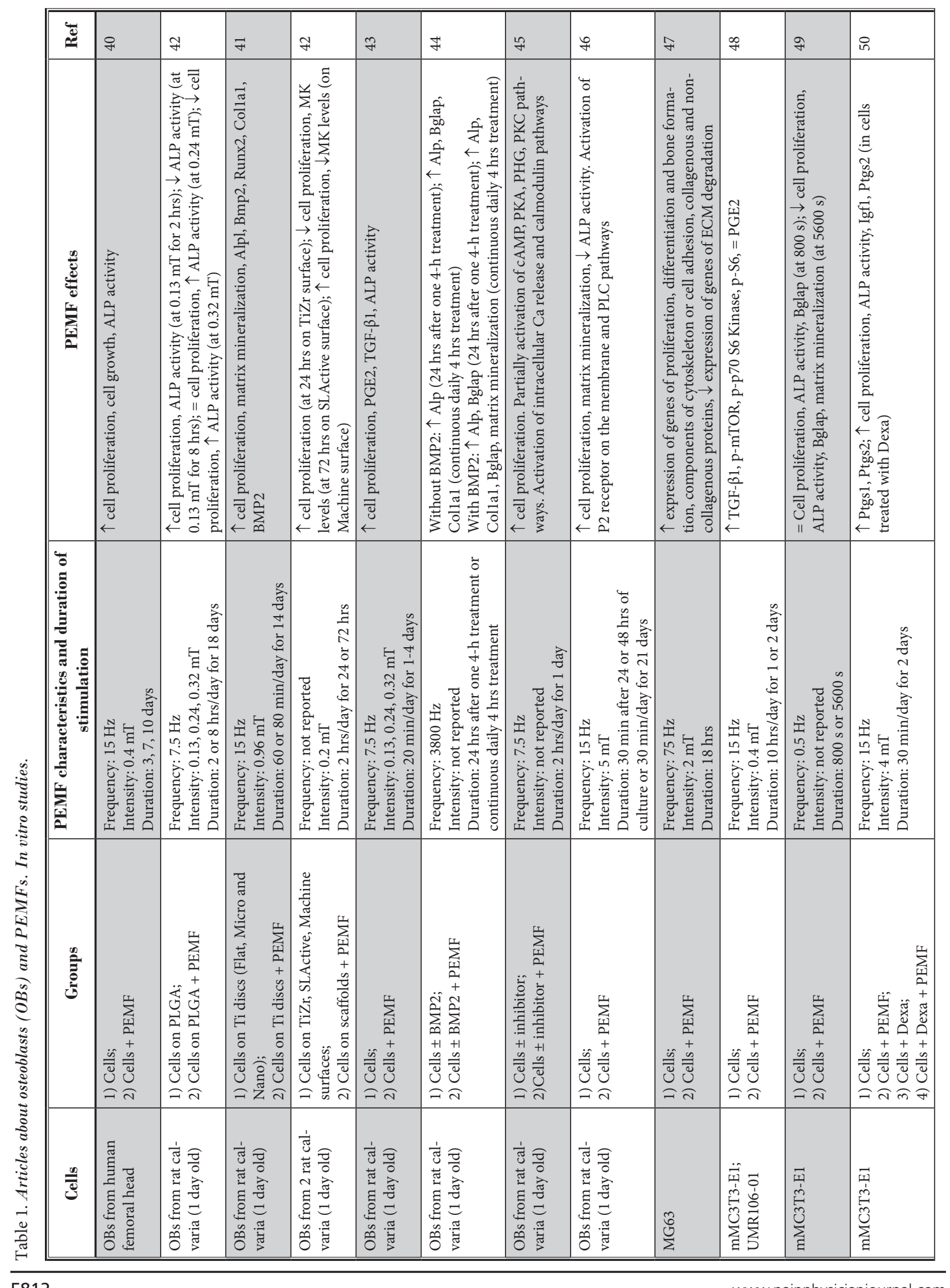




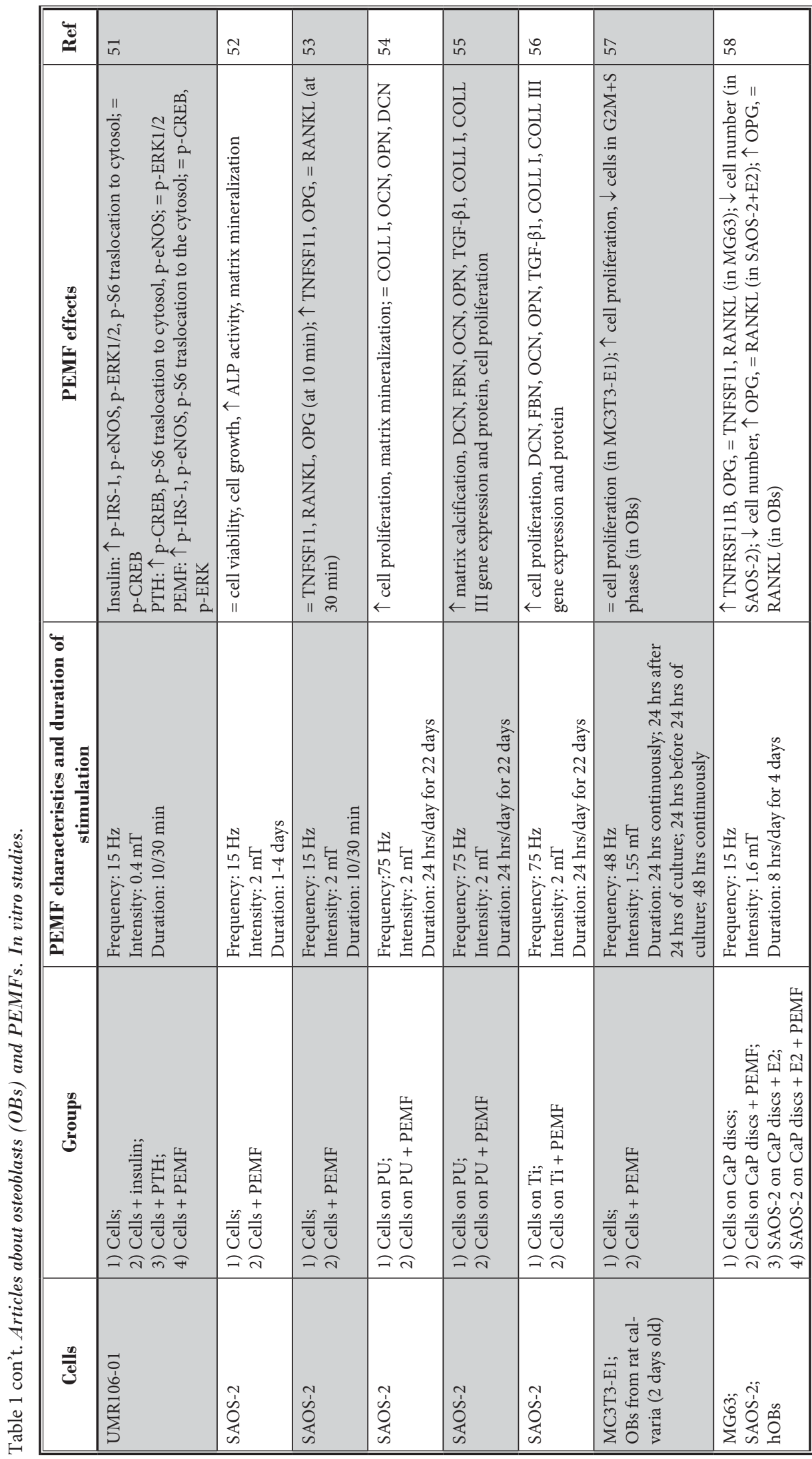

tion factors such as runt-related transcription factor 2 (RUNX2) and osterix (OSX), minor organic components of the matrix such as fibronectin (FBN) and decorin (DCN), and typical proteins of the late differentiation phase such as OCN. They confirmed an improvement of anabolic proteins $(41,55,56,58)$ under PEMF stimulation and a decrease in midkine (MK) levels, an embriogenic protein that reappears in some pathologies (42). However, IcaroCornaglia et al (54) showed an improvement only in cell number and mineralization, and not in protein production. Among these 8 studies, one compared 3 different intensities $(0.13$, 0.24 , and $0.32 \mathrm{mT}$ ), each employed at 2 different times (2 or 8 hours/day), finding that $0.32 \mathrm{mT}$ reduced cell proliferation and increased ALP activity, while $0.13 \mathrm{mT}$ had the opposite effect and $0.24 \mathrm{mT}$ increased only ALP activity (57).

It is also important to note that some authors compared PEMFs with other treatments, such as dexamethasone (Dexa), insulin, and parathyroid hormone (PTH) $(50,51)$, observing the action of single treatments or their synergy. PEMFs, after Dexa treatment, improved cell proliferation, ALP activity, and IGF1 expression, compared to Dexa treatment alone (50). Like insulin treatment, PEMFs phosphorilated IRS- 
1, eNOS, and S6 protein. This was also observed with PTH (51).

\section{Osteoclasts}

In the only 2 in vitro studies about OCs $(59,60)$, PEMF frequencies of 7.5 and $8 \mathrm{~Hz}$ were employed on bone marrow mesenchymal stem cells (BMSCs) harvested from healthy (59) or ovariectomized (60) rats. An increase in OC apoptosis rate was observed after 8 hours of stimulation (59), together with a reduction in gene expression of receptor activator of nuclear factor $\kappa \mathrm{B}$ (RANK) and carbonic anhydrase II (CA II) (60). This enzyme, necessary for the synthesis of carbonic acid, is useful to obtain the acid microenvironment where OCs are active and osteolysis occurs (60) (Table 2).

Taken together, these data revealed a regulatory action of PEMFs in OCs.

\section{Osteoporotic in vivo Models}

Table 3 summarizes the 8 in vivo studies (61-68) showing the positive effects of PEMFs in OP. Even if the duration of the stimulus varied a lot among these studies, most of them employed a frequency of $15 \mathrm{~Hz}$ (4/7), $8 \mathrm{~Hz}(2 / 8)$, or $50 \mathrm{~Hz}(1 / 8)$.

Alternative models were set up to obtain OP: ovariectomy (OVX) (61-66) and disuse (DOP) performed by

Table 2. Articles about osteoclasts (OCs) and PEMFs. In vitro studies.

\begin{tabular}{|l|l|l|l|l||}
\hline \multicolumn{1}{|c|}{ Cells } & \multicolumn{1}{|c|}{ Groups } & $\begin{array}{l}\text { PEMF characteristics and } \\
\text { duration of stimulation }\end{array}$ & \multicolumn{1}{|c|}{ PEMF effects } & Ref \\
\hline $\begin{array}{l}\text { OCs from femurs and tibiae } \\
\text { of female rats (8 mo old) }\end{array}$ & $\begin{array}{l}\text { 1) Cells; } \\
\text { 2) Cells + PEMF }\end{array}$ & $\begin{array}{l}\text { Frequency: } 7.5 \mathrm{~Hz} \\
\text { Intensity: } 0.0008 \mathrm{mT} \\
\text { Duration: } 1,8,16 \mathrm{hrs}\end{array}$ & $\begin{array}{l}\uparrow \text { cell apoptosis (at } 8 \text { and } 16 \mathrm{hrs),} \\
\text { more at } 8 \text { hrs }\end{array}$ & 59 \\
\hline $\begin{array}{l}\text { OCs from 24 OVX female } \\
\text { rats (3 mo old) }\end{array}$ & $\begin{array}{l}\text { 1) Cells from OVX rats; } \\
\text { 2) Cells from OVX rats + PEMF }\end{array}$ & $\begin{array}{l}\text { Frequency: } 8 \mathrm{~Hz} \\
\text { Intensity: } 3.8 \mathrm{mT} \\
\text { Duration: } 40 \mathrm{~min} / \text { day for } 3 \text { days }\end{array}$ & $\downarrow$ Car2 & 60 \\
\hline
\end{tabular}

Table 3. Articles about osteoporosis (OP) and PEMFs. In vivo studies.

\begin{tabular}{|c|c|c|c|c|}
\hline Animals & Groups & $\begin{array}{l}\text { PEMF characteristics and } \\
\text { duration of stimulation }\end{array}$ & PEMF effects & Ref \\
\hline $\begin{array}{l}12 \text { OVX female rats ( } 6 \text { mo old) } \\
\text { with bilateral fibular osteotomy }\end{array}$ & $\begin{array}{l}\text { 1) OVX rats; } \\
\text { 2) OVX rats + PEMF }\end{array}$ & $\begin{array}{l}\text { Frequency: } 15 \mathrm{~Hz} \\
\text { Intensity: } 0.52 \mathrm{mT} \\
\text { Duration: } 3 \mathrm{hrs} / \text { day for } 6 \mathrm{wks}\end{array}$ & $\uparrow$ Biomechanics of the callus & 61 \\
\hline 30 OVX female rats ( 3 mo old) & $\begin{array}{l}\text { 1) OVX rats; } \\
\text { 2) OVX rats + PEMF }\end{array}$ & $\begin{array}{l}\text { Frequency: } 15 \mathrm{~Hz} \\
\text { Intensity: } 2.4 \mathrm{mT} \\
\text { Duration: } 8 \mathrm{hrs} / \text { day for } 10 \mathrm{wks}\end{array}$ & $\begin{array}{l}\uparrow \text { Biomechanics, BMD, bone architec- } \\
\text { ture, Wnt1, Lrp5, Ctnnb1 }\end{array}$ & 62 \\
\hline 30 OVX female rats ( 3 mo old) & $\begin{array}{l}\text { 1) OVX rats; } \\
\text { 2) OVX rats + PEMF }\end{array}$ & $\begin{array}{l}\text { Frequency: } 8 \mathrm{~Hz} \\
\text { Intensity: } 3.8 \mathrm{mT} \\
\text { Duration: } 40 \mathrm{~min} / \text { day, } 5 \text { days/wk } \\
\text { for } 12 \mathrm{wks}\end{array}$ & $\begin{array}{l}\uparrow \text { serum E2, ALP, bone architecture, } \\
\text { biomechanics, Wnt3a, Lrp5, Ctnnb1, } \\
\text { Myc, Runx2, } \downarrow \text { Dkk1 }\end{array}$ & 63 \\
\hline $\begin{array}{l}10 \text { OVX female rats ( } 3 \text { mo } \\
\text { old) with Ti implants in tibia } \\
\text { metaphysis }\end{array}$ & $\begin{array}{l}\text { 1) OVX rats; } \\
\text { 2) OVX rats + PEMF }\end{array}$ & $\begin{array}{l}\text { Frequency: } 50 \mathrm{~Hz} \\
\text { Intensity: } 0.2 \mathrm{mT} \\
\text { Duration: } 4 \mathrm{hrs} / \text { day for } 2 \mathrm{wks}\end{array}$ & $\uparrow$ bone architecture & 64 \\
\hline 30 OVX female rats ( 3 mo old) & $\begin{array}{l}\text { 1) OVX rats; } \\
\text { 2) OVX rats + PEMF }\end{array}$ & $\begin{array}{l}\text { Frequency: } 8 \mathrm{~Hz} \\
\text { Intensity: } 3.8 \mathrm{mT} \\
\text { Duration: } 40 \mathrm{~min} / \text { day, } 5 \text { days/wk } \\
\text { for } 12 \mathrm{wks}\end{array}$ & $\begin{array}{l}\uparrow \text { E2, biomachanics, BMD, Tnfrsf11b, } \\
\downarrow \text { TRACP5b, Tnfsf11 }\end{array}$ & 65 \\
\hline 20 OVX female rats ( 5 mo old) & $\begin{array}{l}\text { 1) OVX rats; } \\
\text { 2) OVX rats + PEMF }\end{array}$ & $\begin{array}{l}4 \text { different treatments protocols; } \\
\text { Duration: } 2 \mathrm{hrs} / \text { day, } 5 \text { days/wk } \\
\text { for } 6 \mathrm{wks}\end{array}$ & $=$ cancellous or cortical bone & 66 \\
\hline 80 DOP female rats (4 mo old) & $\begin{array}{l}\text { 1) DOP rats; } \\
\text { 2) DOP rats + CT; } \\
\text { 3) DOP rats + PEMF }\end{array}$ & $\begin{array}{l}\text { Frequency: } 15 \mathrm{~Hz} \\
\text { Intensity: } 0.8 \mathrm{mT} \\
\text { Duration: } 2 \mathrm{hrs} / \text { day for } 8 \mathrm{wks}\end{array}$ & $\begin{array}{l}\text { CT: } \uparrow \text { BMD, } \downarrow \text { IL6 } \\
\text { PEMF: } \uparrow \text { BMD, TGF- } \beta 1, \downarrow \text { IL6, } \uparrow \\
\text { BMD, TGF- } \beta 1 \text { than CT }\end{array}$ & 67 \\
\hline $30 \mathrm{HU}$ male rats (3 mo old) & $\begin{array}{l}\text { 1) HU rats; } \\
\text { 2) HU rats + PEMF }\end{array}$ & $\begin{array}{l}\text { Frequency: } 15 \mathrm{~Hz} \\
\text { Intensity: } 2.4 \mathrm{mT} \\
\text { Duration: } 2 \mathrm{hrs} / \text { day for } 4 \text { wks }\end{array}$ & $\begin{array}{l}\uparrow \text { OCN, P1NP, biomechanics, BMD, } \\
\text { bone architecture, Wnt1, Lrp5, Ctnnb1, } \\
\text { Tnfrsf11b, Bglap, } \downarrow \text { CTX-I }\end{array}$ & 68 \\
\hline
\end{tabular}


the immobilization of hind limbs by a tibia-tail fixation (67) or by the attachment of the tail to the cage to maintain the rat in $30^{\circ}$ position (68).

To evaluate the effects of PEMFs in osteoporotic animals, the authors analyzed bone biomechanics, mineral density (BMD), and histology, besides the expression of genes involved in bone remodeling. PEMFs increased biomechanical and architectural parameters, such as trabecular number (Tb.N) and thickness (Tb.Th), bone volume (BV/TV) $(61-63,67)$ and BMD $(61,62,64,68)$. However, a decrease in trabecular separation (Tb.Sp) was also observed $(61,62,67)$, although after Ti implants in tibia, an author did not find differences in Tb.Th and Tb.Sp (63).

Most of these studies demonstrated an increase in c-myc, RUNX2, OCN, COLL I, OPG, TGF- $\beta 1$ gene expression and protein production $(62,64,65,67,68)$. In addition, as also observed in the in vitro studies on OBs, an involvement of the Wnt/ $\beta$-catenin pathway was noticed. This not only stimulated bone formation, raising the growth rate of OBs and inhibiting their apoptosis, but also inhibited osteoclastogenesis. In fact, in these studies, PEMFs increased proto-oncogene proteins (WNT-1 and WNT3), low-density lipoprotein receptor-related protein 5 (LRP5) and $\beta$-catenin $(59,60,65)$, decreasedstructure model index (SMI), DickkopfWNT signaling pathway inhibitor 1 (DKK1) and RANKL expression, as well as serum IL-6, involved in the stimulation of osteoclastogenesis, and Cross Linked C-Telopeptide Of Type I Collagen (CTX-I) $(59,60,63,65,66)$.

In 4 studies, in addition to the comparison with nonstimulated osteoporotic animals, the stimulated group was also compared with healthy animals $(61,62,67,68)$, revealing better results in the PEMF group compared to healthy animals in one study (67) and equal results in the others $(61,62,68)$.

Finally, only one study on osteoporotic rats, found no support for the use of PEMF in the treatment of CRPS-I (66).

\section{Inflammation}

Preclinical studies of this topic are divided into those describing the effects of PEMFs in animal models of different inflammatory conditions (arthritis, myopathy, cerebral ischemia, and brain injuries) (69-73) and those using cell types such as peripheral blood mononuclear cells of patients affected by Crohn's disease (74), RAW 264.7 (75), fibroblast-like cells from mononuclear peripheral blood of healthy donors (76), human dermal fibroblasts, epidermal keratinocytes, and mononuclear cells (77) cultured in vitro (Table 4).
These preclinical studies clarify the role of PEMFs on pro-inflammatory cytokines and oxidative damage, which are also involved in CRPS-I.

The study by Eraslan et al (70), performed on blood harvested from healthy mice treated with PEMFs, revealed no PEMFs induced oxidative damage. The levels of enzymes with an antioxidant role, superoxide dismutase (SOD), catalase, glutathione peroxidase (GPx), glucose-6-phosphate dehydrogenase (G6PD), and malondialdehyde (MDA), not only were not altered in the experimental group, but they also showed a weak decrease, although not significant (70).

A reduction in paw volume, thiobarbituric acid reactive substances (TBARS), calcium, and PGE2 levels was observed after PEMF stimulation in a rat model of arthritis, obtained by injecting $0.1 \mathrm{~mL}$ of heat killed $\mathrm{M}$. tubercolosis. This was similar to the results obtained by the treatment with diclofenac. Moreover, PEMFs improved the activities of SOD, catalase, GPx, and GSH, which protect the cell from oxidative damage by reactive oxygen species (ROS) (69).

In a model of rat myopathy, performed by injecting $50 \mu \mathrm{l}$ of $1 \%$ carrageenan lambda, PEMFs reduced the plasma levels of fibrinogen, L-citrulline, NO, SOD activity, and inflammatory infiltrate (71).

The production of pro-inflammatory cytokines was also evaluated in distal middle cerebral artery occlusion (dMCAO), in a mouse model of post-stroke inflammation. The authors observed a reduction in IL $1 \alpha$, TNF- $\alpha$, and ischemic infarct size, but also an increase in IL10 after PEMF treatment, underling the anti-inflammatory and anti-apoptotic role of PEMFs (72). Another study quantified the level of a single inflammatory cytokine (IL1 $\beta$ ) in the cerebrospinal fluid of a rat with 2 traumatic brain injuries, demonstrating a reduction in its levels within 6 or $17-2$ hours of stimulation (73).

Going back to the in vitro studies, peripheral blood mononuclear cells (PBMNCs) from Crohn's disease-affected patients $(74)$ and from healthy donors $(74,76)$ were harvested and stimulated with phytohaemaglutinin (PHA) or lipopolisaccharide (LPS). Cell viability and cytokine profile are crucial after activation of cells with these mytogens, since cells are most susceptible to death during mitosis, when treated with PEMFs.

At $50 \mathrm{~Hz}$ of frequency, PEMF application reduced the viability of PBMNCs, mostly composed of T lymphocytes, which are among the main factors involved in Crohn's disease and other inflammatory diseases. At the same frequency, interferon-gamma (INF $\gamma$ ) release decreased in both healthy and pathological cells induced 
Pain Physician: September/October 2017; 20:E807-E822

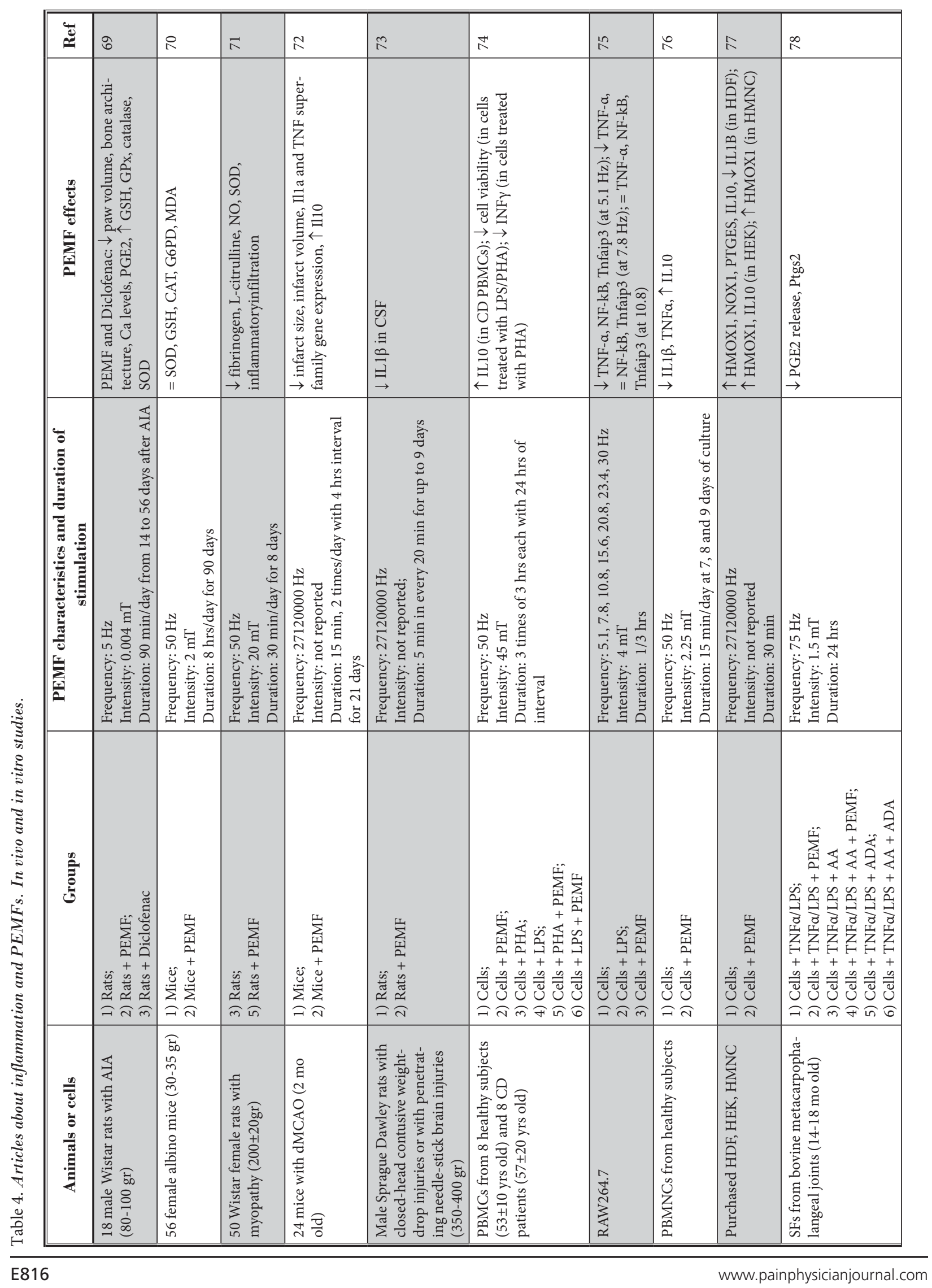




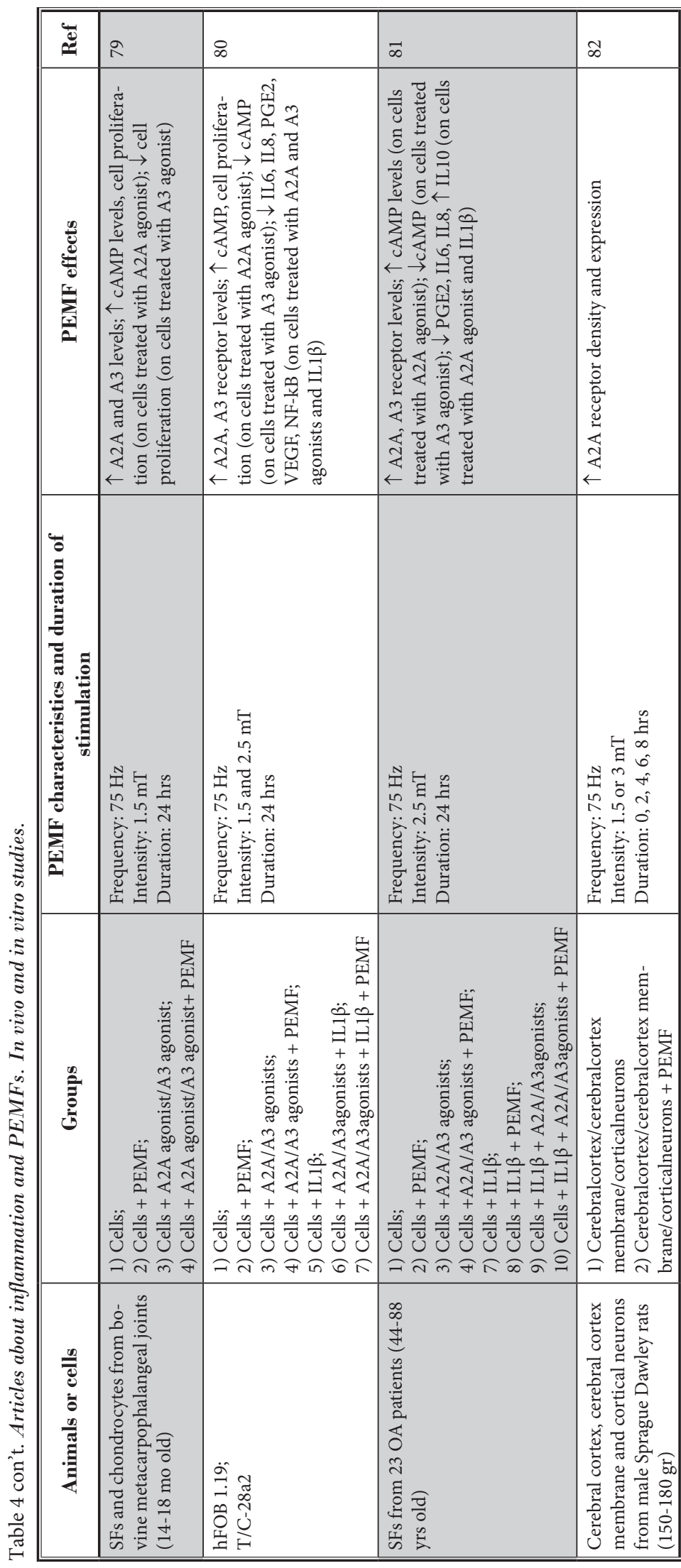

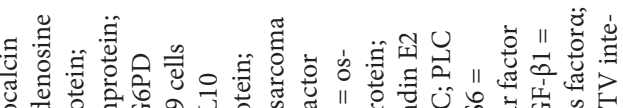

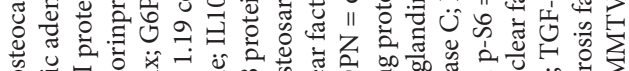

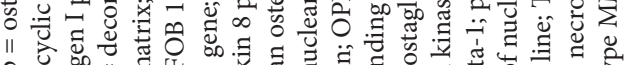

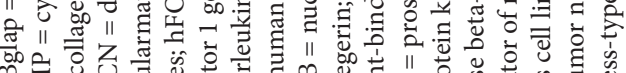

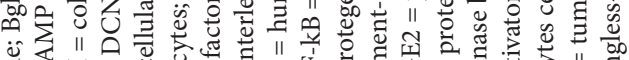

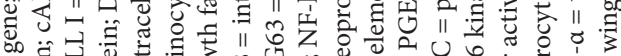

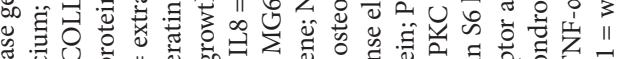

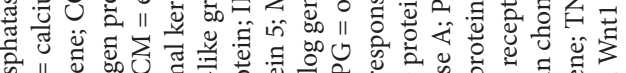

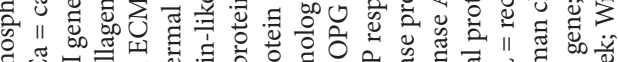

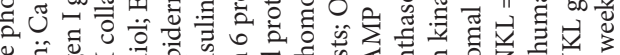

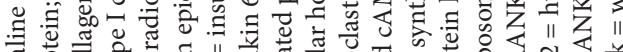

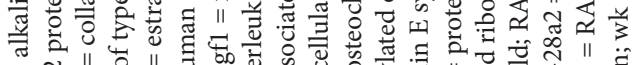
II N II 0 " II

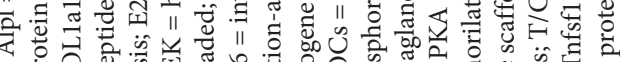

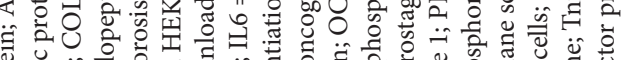

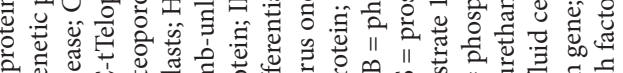

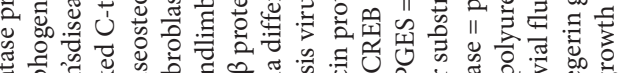

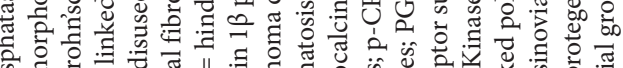

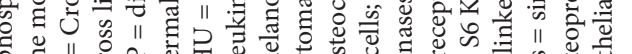

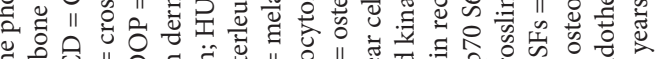
罗

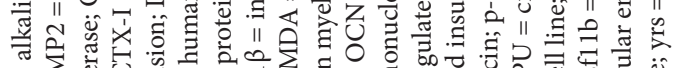

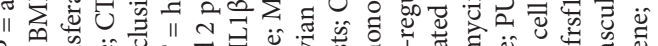

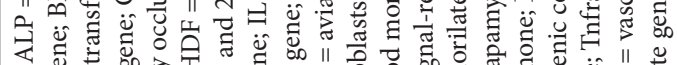

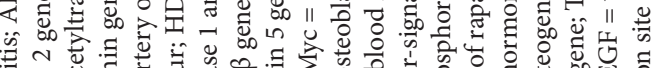

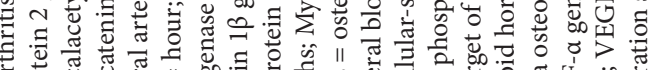

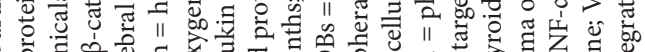

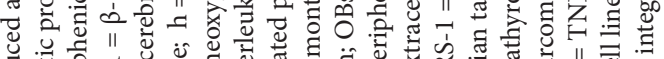

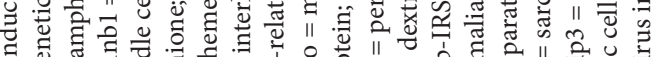

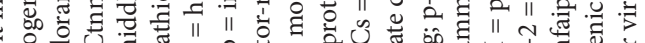

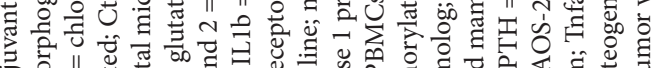

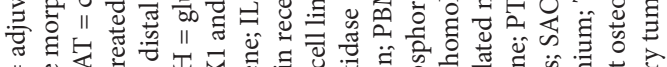

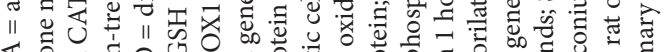

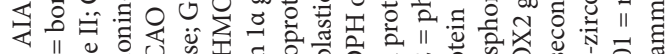

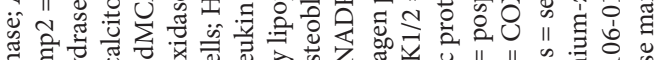
品金

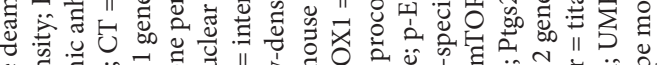

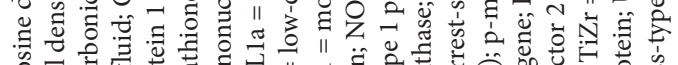

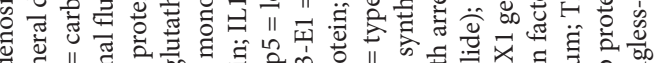
表 II

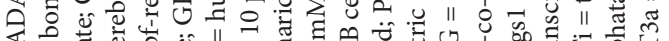

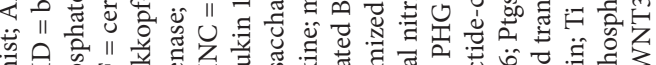

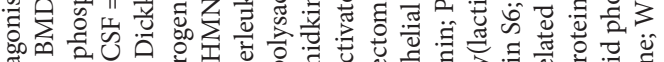
等

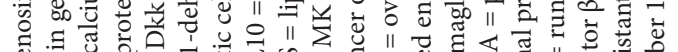

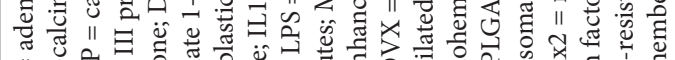

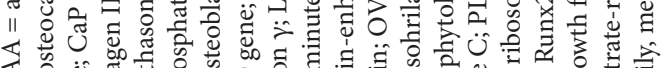

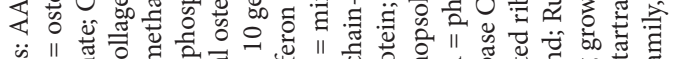

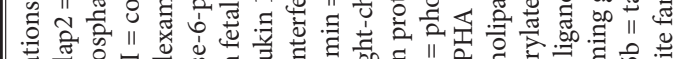

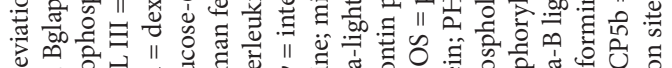

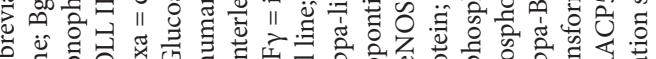

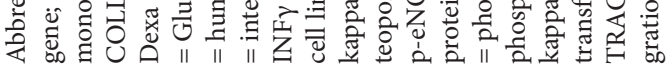


to proliferate (74), increasing the anti-inflammatory cytokine IL10 in Crohn-derived cells stimulated with PEMFs compared to non-stimulated cells.

Similarly, IL1 $\beta$ and TNF- $\alpha$ decreased in fibroblastlike cells derived from MNC of healthy donors or in macrophages cell lines (RAW 264.7) $(75,76)$, increasing the anti-inflammatory cytokine IL10 (76) after PEMF application.

RAW 264.7 cells, relevant because of the involvement of macrophages in the inflammatory process, were treated with LPS and stimulated with 7 different PEMF frequencies $(5.1,7.8,10.8,15.6,20.8,23.4$, and 30 $\mathrm{Hz}$ ): the authors concluded that $5.1 \mathrm{~Hz}$ stimulation reduced TNF- $\alpha$, nuclear factor kappa-light-chain-enhancer of activated B cells (NF-kB) and A20 (tumor necrosis factor-alpha induced protein 3 ), in comparison to nonstimulated cells or cells treated with LPS (75).

In human dermal fibroblasts (HDF), epidermal keratinocytes (HEK), and MNCS, PEMFs increased the expression of heme oxygenase-1 (HOX1), IL10, NADPH oxidase 1 (NOX1), and prostaglandin E synthase (PGES), but reduced the expression of IL1 $\beta$ (77), probably to limit the inflammatory phenomenon and avoid a chronic condition.

In order to understand the cell molecular response to PEMF stimulation in an inflammatory disease, 5 in vitro studies looked at the behavior of adenosine receptors in synovial fibroblasts, chondrocytes, OBs, cerebral cortex, cerebral cortex membrane and cortical neurons (78-82).

Some authors evaluated the density of 4 different adenosine receptors ( $A 1, A 2 A, A 2 B$, and $A 3)$, observing that PEMF increased the number of $A 2 A$ and $A 3$ in healthy bovine synovial fibroblasts and chondrocytes, human fetal OBs and chondrocyte cell lines, and human synovial fibroblasts harvested from osteoarthritic patients (79-81). One study observed an increase in A2A also in the cerebral cortex, cerebral cortex membrane, and cortical neurons (82).

The levels of cyclic adenosine monophosphate (cAMP) increased with the addition of A2A agonist $(80,81)$, and the association of A2A agonist and PEMFs increased cAMP levels even more in comparison to cells treated with or without A2A agonist (79-81), highlighting the role of CAMP as mediator of adenosine receptors activation.

One of the most important aspects related to inflammation, as already mentioned, is the production of prostaglandins. The release of PGE2 and the expression of cyclooxygenase-2 (COX-2) were reduced by A2A ade- nosine agonist and PEMFs in bovine synovial fibroblasts treated with TNF- $\alpha$ or LPS $(78,79)$, in human fetal OBs and chondrocytes $(80,81)$, and in human osteoarthritic synovial fibroblasts (81) stimulated with IL1 $\beta$. In addition, PEMFs with or without A2A and A3 agonists reduced IL6 and IL8 while increased IL10 in osteoarthritic human synovial fibroblasts (81). Finally, PEMFs in presence of A2A and A3 agonists reduced IL6, IL8, vascular endothelial growth factor (VEGF), and NF-kB in human OBs $(80,81)$ (Table 4).

\section{Discussion}

The lack of a unique clinical picture and exhaustive knowledge about CRPS-I and its often-unresolved painful course, induced the authors to carry out this review based on the cornerstones of this morbid condition: inflammation and OP, starting from observations about the behavior of OBs and OCs and referring to the few animal models useful for this purpose.

Current therapeutic approaches are based on the integrated use of physical therapy, occupational therapy, psychological and behavioral approaches, and medications (anti-inflammatory drugs and painkillers, anticonvulsants, antidepressants, opioids, calcitonin, bisphosphonates, dimethyl sulfoxide-DMSO) (8) and on more invasive procedures such as nerve blocks, spinal cord stimulation, up to simpaticectomy.

At present, none of these treatments seem to be able to guarantee full success in $100 \%$ of cases of CRPSI. A recent review by Smart et al (83), focusing on physiatric measures, revealed that there was a low level of evidence on the use of mirror therapy, graded motor imagery (GMI), and PEMF, and absence of evidence on pain regarding other procedures.

The analyzed studies of the present review demonstrated the substantial ability of PEMFs to enhance both proliferation and differentiation of $\mathrm{OBs}$, by stimulating key anabolic bone proteins and by inhibiting matrix degrading enzymes $(34,40-58)$. Bone resorption also appeared inhibited by means of an increased OPG/RANKL ratio, an increased OC apoptosis, and the down regulation of CA II gene expression $(59,60)$.

The main genes and relative proteins stimulated by PEMFs in OBs seemed to include both regulatory and structural proteins. It is well known that the early differentiation phase consists in the secretion of COLL $I$ and ALP (respectively the principal constitutive protein of the matrix and the co-factor of matrix synthesis and hydroxyapathyte deposition) regulated by RUNX-2 transcriptional factor. Subsequently, other fundamental 
proteins take over during the later phase, to complete ECM synthesis, collagen calcification, and final mineralization $(41,55,56)$.

Subsequently and under the effect of OSX as transcriptional factor, other fundamental proteins take over during the later phase: SPARC, involved in eECM synthesis and required for calcification of collagen, and OCN, secreted by mature OBs and binding with high affinity to mineralized matrix $(39,53,54)$.

In both these phases the Wnt signaling pathway is crucial, as it promotes osteoblastogenesis in terms of cell proliferation, differentiation, mineralization of OBs, and apoptosis inhibition, and it also suppresses adipogenesis of BMSCs (84). The involvements of the activated canonical Wnt pathway are manifold on osteoblastogenesis: it promotes proliferation and differentiation of BMSCs, up-regulates OPG, enhances mineralization of OBs, and suppresses their apoptosis (84).

The listed actions are performed involving FZD proteins: the principal receptors for the Wnt family of ligands, together with Lrp5 and Lrp6 coreceptors and $\beta$-catenin in the canonical way (84).

Numerous studies have already investigated this aspect in vivo, observing improved histological features, such as Tb.N, Tb.Th, Tb.Sp, BV/TV, and BMD, confirming the positive effects of PEMFs in osteoporotic animal models (61-68).

Based on the same analogous principle applied to OP, the inflammatory aspect of CRPS-I was taken into account by observing the role of PEMFs in several diseases, which present important inflammatory aspects, and on cells typically involved in the inflammatory process (69-77).

PEMFs showed no detrimental effects, in particular oxidative damages, on the analyzed blood derived healthy cells. Secondly, in inflamed environments the level of NO and PGE2, usually considered markers of inflammatory reaction, appeared decreased except in the paper by Kubat et al (77), who observed an increase of PGES. Kubat et al explained this phenomenon as a necessary switch between pro-inflammatory phase and resolution of inflammation, to avoid a chronic state. In particular, the induction of pro-resolving lipid mediators (e.g., resolvins)via a PGES/lipoxygenase-mediated pathway was the hypothesized biological way to overcome the inflammatory condition (77).

In other studies performed on pro-inflammatory cytokines, both in vitro and in vivo, the decrease of these markers was evident after PEMF treatment, and in parallel with the increase of IL-10, a typical anti-in- flammatory cytokine. Numerous researchers have already examined the cellular mechanism through which PEMFs carry out their anti-inflammatory action: the main players are well known to be adenosine receptors $A 2 A$ and $A 3$, present on chondrocytes, fibroblasts, and even neurons (78-82). These receptors increase after PEMF stimulation, thereby inducing the increase of CAMP levels, known as middle cellular molecule (85).

It is interesting to observe how the positive effects of PEMFs are evident in both acute and chronic inflammatory diseases, making this approach broadly applicable to numerous clinical presentations.

Next to these considerations, however, the role of the physical parameters of PEMFs should not be underestimated, such as intensity, frequency, and time of treatment. Only 2 papers $(34,43)$ compared different intensities in vitro (all performed on rat calvaria OBs), while many papers compared exposure times, pointing out the role of these elements on different results obtained in term of OB proliferation and ALP activity, but also in term of their timing. Conversely, only one study compared different intensities of PEMFs applied to RAW cultures (75), to evaluate some inflammatory parameters.

The findings from the literature are currently quite poor in terms of clinical trials and there is only an example where the effect of PEMFs in combination with calcitonin and stretching was compared with calcitonin, stretching, and placebo. Cochrane, however, considers this trial as low quality evidence (83).

It would be desirable to standardize the experimental conditions to derive the impact of the single parameter on the various cell types more precisely. However, the lack of homogeneity observed in the literature could be useful to confirm a substantial positive effect of PEMFs on OB activity and inflammation.

The results of the studies, analyzed in this review, represent the rationale for the proposed clinical use of PEMFs in CRPS-I, especially considering the many effects that this type of treatment appears to have on OBs, OCs, and inflammation through adenosine receptors. Controlling the inflammatory microenvironment can be important for the success of any treatment targeting both pain and bone metabolism.

The interest should now be directed to the development of clinical trials which can provide adequate evidence, especially regarding the possibility of using PEMFs not as a single treatment, but in combination with other therapeutic measures. 


\section{Acknowledgments}

The authors declare no conflict of interests. This work was supported by grants from Rizzoli Orthopedic Institute (Ricerca Corrente) and by the Operational Pro- gramme ERDF 2007-2013 in the region Emilia-Romagna: Activity The 1.1 "Creation of technology centers for Industrial research and technological transfer."

\section{References}

1. Staunton H. Sudeck atrophy. Ir Med J 2006; 99:313-315.

2. Casale R, Atzeni F, Sarzi-Puttini P. From Mitchell's causalgia to complex regional pain syndromes: 150 years of definitions and theories. Clin Exp Rheumatol 2015; 33:S7-S13.

3. Dutton K, Littlejohn G. Terminology, criteria, and definitions in complex regional pain syndrome: Challenges and solutions. J Pain Res 2015; 8:871-877.

4. Varenna M, Zucchi F. Algodystrophy: Recent insight into the pathogenic framework. Clin Cases Miner Bone Metab 2015; 12:27-30.

5. Omoigui $\mathrm{S}$. The biochemical origin of pain: The origin of all pain is inflammation and the inflammatory response. Part 2 of 3 -inflammatory profile of pain syndromes. Med Hypotheses 2007; 69:11691178.

6. Heijmans-Antonissen C, Wesseldijk F, Munnikes RJ, Huygen FJ, van der Meijden P, Hop WC, Hooijkaas H, Zijlstra FJ. Multiplex bead array assay for detection of 25 soluble cytokines in blister fluid of patients with complex regional pain syndrome type 1. Mediators Inflamm 2006; 2006:28398.

7. Huygen FJ, Ramdhani N, van Toorenenbergen A, Klein J, Zijlstra FJ. Mast cells are involved in inflammatory reactions during complex regional pain syndrome type 1. Immunol Let 2004; 91:147-154.

8. Wertli MM, Kessels AG, Perez RS, Bachmann LM, Brunner F. Rational pain management in complex regional pain syndrome 1 (CRPS 1 ) - a network metaanalysis. Pain Med 2014; 15:1575-1589.

9. Weintraub MI. Magnetotherapy: Historical background with a stimulating future. Critical Reviews in Physical and Rehabilitation Medicine 2004; 16:95-108.

10. Wade B. A review of pulsed electromagnetic field (PEMF) mechanisms at a cellular level: A rationale for clinical use. American Journal of Health Research 2013; 1:51-55.

11. Rubin CT, McLeod KJ, Lanyon LE. Prevention of osteoporosis by pulsed elec- tromagnetic fields. ] Bone Joint Surg Am 1989; 71:411-417.

12. Della Bella E, Tschon M, Stagni C, Dallari D, Fini M. Biophysical stimulation for nonunions. J Biol Regul Homeost Agents 2015; 29:25-38.

13. Veronesi F, Cadossi M, Giavaresi G, Martini L, Setti S, Buda R, Giannini S, Fini M. Pulsed electromagnetic fields combined with a collagenous scaffold and bone marrow concentrate enhance osteochondral regeneration: $A n$ in vivo study. BMC Musculoskelet Disord 2015; 16:233.

14. Veronesi F, Fini M, Giavaresi G, Ongaro A, De Mattei M, Pellati A, Setti S, Tschon $M$. Experimentally induced cartilage degeneration treated by pulsed electromagnetic field stimulation; an in vitro study on bovine cartilage. BMC Musculoskelet Disord 2015; 16:308.

15. Veronesi F, Torricelli P, Giavaresi G, Sartori M, Cavani F, Setti S, Cadossi M, Ongaro $A$, Fini $M$. In vivo effect of two different pulsed electromagnetic field frequencies on osteoarthritis. J Orthop Res 2014; 32:677-685.

16. Ongaro A, Pellati A, Masieri FF, Caruso A, Setti S, Cadossi R, Biscione R, Massari L, Fini M, De Mattei M. Chondroprotective effects of pulsed electromagnetic fields on human cartilage explants. Bioelectromagnetics 2011; 32:543-551.

17. Li S, Luo Q, Huang L, Hu Y, Xia Q, He C. Effects of pulsed electromagnetic fields on cartilage apoptosis signaling pathways in ovariectomised rats. Int Orthop 2011; 35:1875-1882.

18. Boopalan PR, Arumugam S, Livingston A, Mohanty M, Chittaranjan S. Pulsed electromagnetic field therapy results in healing of full thickness articular cartilage defect. Int Orthop 2011; 35:143-148.

19. Benazzo F, Cadossi M, Cavani F, Fini M, Giavaresi G, Setti S, Cadossi R, Giardino R. Cartilage repair with osteochondral autografts in sheep: Effect of biophysical stimulation with pulsed electromagnetic fields. J Orthop Res 2008; 26:631-642.

20. Jahns ME, Lou E, Durdle NG, Bagnall K, Raso VJ, Cinats D, Barley RD, Cinats
J, Jomha NM. The effect of pulsed electromagnetic fields on chondrocyte morphology. Med Biol Eng Comput 2007; 45:917-925.

21. Fini $M$, Torricelli $P$, Giavaresi G, Aldini NN, Cavani F, Setti S, Nicolini A, Carpi A, Giardino R. Effect of pulsed electromagnetic field stimulation on knee cartilage, subchondral and epyphiseal trabecular bone of aged Dunkin Hartley guinea pigs. Biomed Pharmacother 2008; 62:709-715.

22. De Mattei $M$, Fini $M$, Setti $S$, Ongaro $A$, Gemmati D, Stabellini G, Pellati A, Caruso A. Proteoglycan synthesis in bovine articular cartilage explants exposed to different low-frequency low-energy pulsed electromagnetic fields. Osteoarthritis Cartilage 2007; 15:163-168.

23. Fini M, Pagani S, Giavaresi G, De Mattei $M$, Ongaro $A$, Varani $K$, Vincenzi $F$, Massari L, Cadossi M. Functional tissue engineering in articular cartilage repair: Is there a role for electromagnetic biophysical stimulation? Tissue Eng Part B Rev 2013; 19:353-367.

24. Petecchia L, Sbrana F, Utzeri R, Vercellino M, Usai C, Visai L, Vassalli M, Gavazzo $P$. Electro-magnetic field promotes osteogenic differentiation of BM-hMSCs through a selective action on $\mathrm{Ca}(2+)$-related mechanisms. Sci Rep 2015; 5:13856.

25. Wang Q, Wu W, Han X, Zheng A, Lei S, Wu J, Chen $\mathrm{H}, \mathrm{He} C$, Luo F, Liu X. Osteogenic differentiation of amniotic epithelial cells: Synergism of pulsed electromagnetic field and biochemical stimuli. BMC Musculoskelet Disord 2014; 15:271.

26. Ongaro A, Pellati A, Bagheri L, Fortini C, Setti S, De Mattei M. Pulsed electromagnetic fields stimulate osteogenic differentiation in human bone marrow and adipose tissue derived mesenchymal stem cells. Bioelectromagnetics 2014; 35:426-436.

27. Fu YC, Lin CC, Chang JK, Chen $\mathrm{CH}$, Tai IC, Wang GJ, Ho ML. A novel single pulsed electromagnetic field stimulates osteogenesis of bone marrow mesen- 
chymal stem cells and bone repair. PLoS One 2014; 9:e91581.

28. Ceccarelli G, Bloise N, Mantelli M, Gastaldi G, Fassina L, De Angelis MG, Ferrari D, Imbriani M, Visai L. A comparative analysis of the in vitro effects of pulsed electromagnetic field treatment on osteogenic differentiation of two different mesenchymal cell lineages. Biores Open Access 2013; 2:283-294.

29. Kaivosoja E, Sariola V, Chen Y, Konttinen YT. The effect of pulsed electromagnetic fields and dehydroepiandrosterone on viability and osteo-induction of human mesenchymal stem cells. J Tissue Eng Regen Med 2015; 9:31-40.

30. Li X, Zhang M, Bai L, Bai W, Xu W, Zhu $\mathrm{H}$. Effects of $50 \mathrm{~Hz}$ pulsed electromagnetic fields on the growth and cell cycle arrest of mesenchymal stem cells: An in vitro study. Electromagn Biol Med 2012; 31:356-364.

31. Teven CM, Greives M, Natale RB, Su Y, Luo Q, He BC, Shenaq D, He TC, Reid RR. Differentiation of osteoprogenitor cells is induced by high-frequency pulsed electromagnetic fields. J Craniofac Surg 2012; 23:586-593.

32. Esposito M, Lucariello A, Riccio I, Riccio V, Esposito V, Riccardi G. Differentiation of human osteoprogenitor cells increases after treatment with pulsed electromagnetic fields. In Vivo 2012; 26:299304 .

33. Jansen JH, van der Jagt OP, Punt BJ, Verhaar JA, van Leeuwen JP, Weinans $H$, Jahr $\mathrm{H}$. Stimulation of osteogenic differentiation in human osteoprogenitor cells by pulsed electromagnetic fields: An in vitro study. BMC Musculoskelet Disord 2010; 11:188.

34. Tsai MT, Chang WH, Chang K, Hou RJ, Wu TW. Pulsed electromagnetic fields affect osteoblast proliferation and differentiation in bone tissue engineering. Bioelectromagnetics 2007; 28:519-528.

35. Sun LY, Hsieh DK, Yu TC, Chiu HT, Lu SF, Luo GH, Kuo TK, Lee OK, Chiou TW. Effect of pulsed electromagnetic field on the proliferation and differentiation potential of human bone marrow mesenchymal stem cells. Bioelectromagnetics 2009; 30:251-260.

36. Schwartz Z, Simon BJ, Duran MA, Barabino G, Chaudhri R, Boyan BD. Pulsed electromagnetic fields enhance BMP-2 dependent osteoblastic differentiation of human mesenchymal stem cells. J Orthop Res 2008; 26:1250-1255.

37. Seeliger C, Falldorf K, Sachtleben J, van Griensven M. Low-frequency pulsed electromagnetic fields significantly improve time of closure and proliferation of human tendon fibroblasts. Eur J Med Res 2014; 19:37.

38. Strauch B, Patel MK, Rosen DJ, Mahadevia S, Brindzei N, Pilla AA. Pulsed magnetic field therapy increases tensile strength in a rat Achilles' tendon repair model. J Hand Surg Am 2006; 31:131-135.

39. Durmus A, Cakmak A, Disci R, Muslumanoglu $L$. The efficiency of electromagnetic field treatment in complex regional pain syndrome type I. Disabil Rehabil 2004; 26:537-545.

40. Barnaba S, Papalia R, Ruzzini L, Sgambato A, Maffulli N, Denaro V. Effect of pulsed electromagnetic fields on human osteoblast cultures. Physiother Res Int 2013; 18:109-114.

41. Wang J, An Y, Li F, Li D, Jing D, Guo T, Luo E, Ma C. The effects of pulsed electromagnetic field on the functions of osteoblasts on implant surfaces with different topographies. Acta Biomater 2014; 10:975-985.

42. Atalay B, Aybar B, Erguven M, Emes Y, Bultan Ö, Akça K, Yalçin S, Baysal U, Isssever H, Çehreli MC, Bilir A.The effects of pulsed electromagnetic field (PEMF) on osteoblast-like cells cultured on titanium and titanium-zirconium surfaces. J Craniofacial Surg 2013; 24:2127-2134.

43. Li JK-J, Lin JCA, Liu HC,Sun JS, Ruaan RC, Shih C, Chang WH. Comparison of ultrasound and electromagnetic field effects on osteoblast growth. Ultrasound Med Biol 2006; 32:769-775.

44. Selvamurugan N, Kwok S, Vasilov A, Jefcoat SC, Partridge NC. Effects of BMP2 and pulsed electromagnetic field (PEMF) on rat primary osteoblastic cell proliferation and gene expression. J Orthop Res 2007; 25:1213-1220.

45. Li JK, Lin JC, Liu HC, Chang WH. Cytokine release from osteoblasts in response to different intensities of pulsed electromagnetic field stimulation. Electromagn Biol Med 2007; 26:153-165.

46. Zhang X, Zhang J, Qu X, Wen J. Effects of different extremely low-frequency electromagnetic fields on osteoblasts. Electromagn Biol Med 2007; 26:167-177.

47. Sollazzo V, Palmieri A, Pezzetti F, Massari L, Carinci F. Effects of pulsed electromagnetic fields on human osteoblastlike cells (MG-63): A pilot study. Clin Orthop Relat Res 2010; 468:2260-2277.

48. Patterson TE, Sakai Y, Grabiner MD, Ibiwoye M, Midura RJ, Zborowski M, Wolfman A. Exposure of murine cells to pulsed electromagnetic fields rapidly activates them TOR signaling pathway. Bioelectromagnetics 2006; 27:535-544.

49. Li K, Ma S, Li Y, Ding G, Teng Z, Liu J, Ren D, Guo Y, Ma L, Guo G. Effects of PEMF exposure at different pulses on osteogenesis of $\mathrm{MC}_{3} \mathrm{~T}_{3}-\mathrm{E}_{1}$ cells. Arch Oral Bio 2014; 59:921-927.

50. Esmail MY, Sun L, Yu L, Xu H, Shi L, Zhang J. Effects of PEMF and glucocorticoids on proliferation and differentiation of osteoblasts. Electromagn Biol Med 2012; 31:375-381.

51. Schnoke M, Midura RJ. Pulsed electromagnetic fields rapidly modulate intracellular signaling events in osteoblastic cells: Comparison to parathyroid hormone and insulin. ] Orthop Res 2007; 25:933-940.

52. Martino CF, Belchenko D, Ferguson V, Nielsen-Preiss S, Qi HJ. The effects of pulsed electromagnetic fields on the cellular activity of SaOS-2 cells. Bioelectromagnetics 2008; 29:125-132.

53. Borsje MA, Ren Y, de Haan-Visser HW, Kuijer R. Comparison of low-intensity pulsed ultrasound and pulsed electromagnetic field treatments on OPG and RANKL expression in human osteoblast-like cells. Angle Orthod 2010; 80:498-503.

54. Icaro Cornaglia A, Casasco M, Riva F, Farina A, Fassina L, Visai L, Casasco A. Stimulation of osteoblast growth by an electromagnetic field in a model of bone-like construct. Eur J Histochem 2006; 50:199-204.

55. Fassina L, Visai L, Benazzo F, Benedetti L, Calligaro A, De Angelis MG, Farina A, Maliardi V, Magenes G. Effects of electromagnetic stimulation on calcified matrix production by SAOS-2 cells over a polyurethaneporous scaffold. Tissue Eng 2006; 12:1985-1999.

56. Fassina L, Saino E, Visai L, Silvani G, Cusella De Angelis MG, Mazzini G, Benazzo F, Magenes G. Electromagnetic enhancement of a culture of human SAOS-2 osteoblasts seeded onto titanium fiber-meshscaffolds. J Biomed Mater Res A 2008; 87:750-759.

57. Wei Y, Xiaolin H, Tao S. Effects of extremely low-frequency-pulsed electromagnetic field on different-derived osteoblast-like cells. Electromagn Biol Med 2008; 27:298-311.

58. Schwartz Z, Fisher $\mathrm{M}$, Lohmann $\mathrm{CH}$, Simon BJ, Boyan BD. Osteoprotegerin (OPG) production by cells in the osteoblast lineage is regulated by pulsed electromagnetic fields in cultures grown 
on calcium phosphate substrates. Ann Biomed Eng 2009; 37:437-444.

59. Chang K, Chang WHS, Tsai MT, Shih C. Electromagnetic fields accelerate apoptotic rate in osteoclasts. Connect Tissue Res 2006; 47:222-228.

6o. Chen J, He HC, Xia QJ, Huang LQ, Hu $Y$ J, He CQ. Effects of pulsed electromagnetic fields on the mRNA expression of RANK and CAll in ovariectomized rat osteoclast-like cell. Connect Tissue Res 2010; 51:1-7.

61. Androjna C, Fort B, Zborowski M, Midura RJ. Pulsed electromagnetic field treatment enhances healing callus biomechanical properties in an animal model of osteoporotic fracture. Bioelectromagnetics 2014; 35:396-405.

62. Jing D, Li F, Jiang M, Cai J, Wu Y, Xie K, Wu X, Tang C, Liu J, Guo W, Shen G, Luo E. Pulsed electromagnetic fields improve bone microstructure and strength in ovariectomized rats through a Wnt/ Lrp5/ $\beta$-catenin signaling-associated mechanism. PLoS One 2013; 8:e79377.

63. Zhou J, He H, Yang L, Chen S, Guo H, Xia L, Liu H, Qin Y, Liu C, Wei X, Zhou Y, $\mathrm{He}$ C. Effects of pulsed electromagnetic fields on bone mass and $W \mathrm{nt} / \beta$-catenin signaling pathway in ovariectomized rats. Arch Med Res 2012; 43:274-282.

64. Akca K, Sarac E, Baysal U, Fanuscu M, Chang TL, Cehreli M. Micro-morphologic changes around biophysically stimulated titanium implants in ovariectomized rats. Head Face Med 2007; 3:28.

65. Zhou J, Chen S, Guo H, Xia L, Liu H, Qin $\mathrm{Y}, \mathrm{He} \mathrm{C}$. Pulsed electromagnetic field stimulates osteoprotegerin and reduces RANKL expression in ovariectomized rats. Rheumatol Int 2013; 33:1135-1141.

66. Van Der Jagt OP, van der Linden JC, Waarsing $\mathrm{JH}$, Verhaar JA, Weinans $\mathrm{H}$. Systemic treatment with pulsed electromagnetic fields do not affect bone microarchitecture in osteoporotic rats. Int Orthop 2012; 36:1501-1506.

67. Shen WW, Zhao JH. Pulsed electromagnetic fields stimulation affects BMD and local factor production of rats with disuse osteoporosis. Bioelectromagnetics 2010; 31:113-119.

68. Jing D, Cai J, Wu Y, Shen G, Li F, Xu Q, Xie K, Tang C, Liu J, Guo W, Wu X, Jiang $M$, Luo E. Pulsed electromagnetic fields partially preserve bone mass, microar- chitecture, and strength by promoting bone formation in hindlimb-suspended rats. J Bone Miner Res 2014; 29:22502261.

69. Selvam R, Ganesan K, Narayana Raju KV, Gangadharan AC, Manohar BM, Puvanakrishnan R. Low frequency and low intensity pulsed electromagnetic field exerts its antiinflammatory effect through restoration of plasma membrane calcium ATPase activity. Life Sci 2007; 80:2403-2410.

70. Eraslan G, Bilgili A, Akdogan M, Yarsan E, Essiz D, Altintas L. Studies on antioxidant enzymes in mice exposed to pulsed electromagnetic fields. Ecotoxicol Environ Saf 2007; 66:287-289.

71. Vignola MB, Davila S, Cremonezzi D, Simes JC, Palma JA, Campana VR. Evaluation of inflammatory biomarkers associated with oxidative stress and histological assessment of magnetic therapy on experimental myopathy in rats. Electromagn Biol Med 2012; 31:320-332.

72. Pena-Philippides JC, Yang $\mathrm{Y}$, Bragina O,Hagberg S, Nemoto E, Roitbak T. Effect of pulsed electromagnetic field (PEMF) on infarct size and inflammation after cerebral ischemia in mice. Transl Stroke Res 2014; 5:491-500.

73. Rasouli J, Lekhraj R, White NM, Flamm ES, Pilla AA, Strauch B, Casper D. Attenuation of interleukin-ıbeta by pulsed electromagnetic fields after traumatic brain injury. Neurosci Lett 2012; 519:4-8.

74. Kaszuba-Zwoińska J, Ciećko-Michalska I, Madroszkiewicz D,Mach T, SłodowskaHajduk Z, Rokita E, Zaraska W, Thor P. Magnetic field anti-inflammatory effects in Crohn's disease depends upon viability and cytokine profile of the immune competent cells. J Physiol Pharmacol 2008; 59:177-187.

75. Ross CL, Harrison BS. Effect of pulsed electromagnetic field on inflammatory pathway markers in RAW 264.7 murine macrophages. J Inflamm Res 2013; 6:4551.

76. Gomez-Ochoa I, Gomez-Ochoa P, Gomez-Casal F, Cativiela E, Larrad-Mur L. Pulsed electromagnetic fields decrease proinflammatory cytokine secretion (IL$1 \beta$ and TNF- $\alpha$ ) on human fibroblast-like cell culture. Rheumatol Int 2011; 31:12831289.

77. Kubat NJ, Moffett J, Fray LM. Effect of pulsed electromagnetic field treatment on programmed resolution of inflammation pathway markers in human cells in culture. J Inflamm Res 2015; 8:59-69.

78. De Mattei M, Varani K, Masieri FF, Pellati A, Ongaro A, Fini M, Cadossi R, Vincenzi F, Borea PA, Caruso A. Adenosine analogs and electromagnetic fields inhibit prostaglandin E2 release in bovine synovial fibroblasts. Osteoarthritis Cartilage 2009; 17:252-262.

79. Varani K, De Mattei M, Vincenzi F, Gessi S, Merighi S, Pellati A, Ongaro A, Caruso A, Cadossi R, Borea PA. Characterization of adenosine receptors in bovine chondrocytes and fibroblast-like synoviocytes exposed to low frequency low energy pulsed electromagnetic fields. Osteoarthritis Cartilage 2008; 16:292-304.

8o. Vincenzi F, Targa M, Corciulo C, Gessi S, Merighi S, Setti S, Cadossi R, Goldring MB, Borea PA, Varani K. Pulsed electromagnetic fields increased the anti-inflammatory effect of $\mathrm{A}_{2} \mathrm{~A}$ and $\mathrm{A}_{3}$ adenosine receptors in human $\mathrm{T} / \mathrm{C}-28 \mathrm{a} 2$ chondrocytes and hFOB 1.19 osteoblasts. PLoS One 2013; 8:e65561.

81. Ongaro A, Varani K, Masieri FF, Pellati A, Massari L, Cadossi R, Vincenzi F, Borea PA, Fini M, Caruso A, De Mattei M. Electromagnetic fields (EMFs) and adenosine receptors modulate prostaglandin $E(2)$ and cytokine release in human osteoarthritic synovial fibroblasts. J Cell Physiol 2012; 227:2461-2469.

82. Varani K, Vincenzi F, Targa M, Corciulo C, Fini M, Setti S, Cadossi R, Borea PA. Effect of pulsed electromagnetic field exposure on adenosine receptors in rat brain. Bioelectromagnetics 2012; 33:279287.

83. Smart KM, Wand BM, O'Connell NE. Physiotherapy for pain and disability in adults with complex regional pain syndrome (CRPS) types I and II. Cochrane Database Syst Rev 2016; 2:CDo10853.

84. Zhai $M$, Jing $D$, Tong $S$, Wu Y, Wang $P$, Zeng Z, Shen G, Wang X, Xu Q, Luo E. Pulsed electromagnetic fields promote in vitro osteoblastogenesis through a Wnt/ $\beta$-catenin signaling-associated mechanism. Bioelectromagnetics 2016 [Epub ahead of print].

85. Borea PA, Varani K, Vincenzi F, Baraldi PG, Tabrizi MA, Merighi S, Gessi S. The $A_{3}$ adenosine receptor: History and perspectives. Pharmacol Rev 2015; 67:74-102. 